\title{
Upper extremity vein thrombosis: an alert symptom of breast cancer in elderly patients. Experience on personal casuistry and review of the literature
}

\author{
Raffaele Serra ${ }^{1 *}$, Rita Compagna ${ }^{4}$, Raffaele Grande ${ }^{2}$, Paolo Perri ${ }^{2}$, Gianluca Buffone ${ }^{2}$, Vincenzo Gasbarro ${ }^{3}$, \\ Antonello Accurso ${ }^{4}$, Michele Danzil, Giovanni Aprea ${ }^{4}$, Bruno Amato ${ }^{4}$, Stefano de Franciscis ${ }^{1}$
}

From 26th National Congress of the Italian Society of Geriatric Surgery

Naples, Italy. 19-22 June 2013

\begin{abstract}
Background: Breast Cancer in elderly patients is a significant health problem representing an important source of morbidity and mortality. Although the most common presentation is the presence of a palpable lump there may be, especially in the elderly population, rare clinical manifestations such as thromboembolic events that often involve the upper limbs.
\end{abstract}

Methods: We retrospectively reviewed a ten year clinical casuistry of patients with Breast Cancer who presented for an initial diagnosis of upper extremity vein thrombosis.

Results: 13 patients with initial diagnosis of upper limbs vein thrombosis (1M-12 F; age range 48-76; median age 70 years) resulted affected from Breast Cancer. The diagnosis of vein thrombosis represented the first clinical manifestation related to thier malingancy. All patients of our casuistry had positive ER/PR receptor status.

Conclusions: A case of upper vein extrmity thrombosis in an elderly patient should prompt a high index of suspicion for breast malignancy in order to avoid diagnostic delay that may retard appropriate treatment.

\section{Background}

Although the number of elderly patients with breast cancer $(\mathrm{BC})$ is increasing, knowledge regarding clinical characteristics and biology of this disease in old age is limited [1].

$\mathrm{BC}$ and Venous Thromboembolism (VTE) are two conditions often correlated more than expected [2-6].

Some studies demonstrated a higher number of ER/PR expression in older patients [1] and another recent retrospective cohort ctudy showed that clinical manifestations related to alterations of circulatory venous system

\footnotetext{
* Correspondence: rserra@unicz.it

${ }^{1}$ Interuniversity Center of Phlebolymphology - Headquorters at University Magna Graecia of Catanzaro - Viale Europa, Località Germaneto - 88100 Catanzaro, Italy

Full list of author information is available at the end of the article
}

are highly prevalent in patients with $\mathrm{BC}$ with positive ER and/or PR status [3].

Aim of this study is to review our clinical casuistry of patients with $\mathrm{BC}$ who presented at our clinical departments with initial diagnosis of upper extremities vein thrombosis.

\section{Methods}

After obtaining institutional review board approval, we retrospectively reviewed the charts of 13 patients (1M$12 \mathrm{~F}$; age range 48-76; median age 70 years) presented with a new breast cancer diagnosis together with a concomitant upper extremity vein thrombosis. The casuistry belonged to three Clinical Departments of the Interuniversity Center of Phlebolymphology.

\section{Biomed Central}

(c) 2013 Serra et al.; licensee BioMed Central Ltd. This is an open access article distributed under the terms of the Creative Commons Attribution License (http://creativecommons.org/licenses/by/2.0), which permits unrestricted use, distribution, and reproduction in any medium, provided the original work is properly cited. 
Demographics and clnical characteristics are reported in Table 1.

\section{Results and discussion}

In our casuistry, in a 10 years period, 13 patients presented with a several week history of painful upper extremities edema.

An initial diagnosis of upper extremity vein thrombosis was made. Subclavian/axillary veins were involved in $76.92 \%$, Brachial vein in $15.38 \%$ and Cephalic vein in $7.69 \%$ of cases.

All patients denied past history of vascular thrombosis, pulmonary embolism or recent surgery on the affected arm. Breast examination revelead symmetrical breast without skin dimpling or nipple retraction except in one case previously described in which a small area with a slight dimpling of the skin and formation of wrinkles was noted [4].

All patients were examined for a possible breast malignancy and dignosis of $\mathrm{BC}$ was confirmed clinically and instrumentally as described in Tab. I.

All patients underwent anticoagulant therapy with low molecular weight heparin for vein thrombosis and subsequent adapted surgical and/or medical treatment for their cancer conditions as previosuly described [2-4].

Table 1 Baseline Patients Characteristics

\begin{tabular}{|c|c|c|}
\hline Population study & & $\%$ \\
\hline Number of patients & 13 & 100 \\
\hline Sex (M/F) & $1 / 12$ & $7.69 \% / 92.31 \%$ \\
\hline $\begin{array}{l}\text { Age } \\
\text { Range } 48-76 \\
\text { median age } 70 \\
48-65 \\
66-70 \\
70+ \\
\end{array}$ & $\begin{array}{l}2 \\
6 \\
5\end{array}$ & $\begin{array}{l}15.38 \% \\
46.15 \% \\
38.46 \%\end{array}$ \\
\hline $\begin{array}{l}\text { BC stage } \\
\text { Stage I } \\
\text { Stage II } \\
\text { Stage III } \\
\text { Stage IV }\end{array}$ & $\begin{array}{l}1 \\
3 \\
5 \\
4\end{array}$ & $\begin{array}{l}7.69 \% \\
23.08 \% \\
38.46 \% \\
30.76 \%\end{array}$ \\
\hline $\begin{array}{l}\text { BC Histology } \\
\text { Ductal } \\
\text { Lobular }\end{array}$ & $\begin{array}{l}9 \\
4\end{array}$ & $\begin{array}{l}69.23 \% \\
30.77 \%\end{array}$ \\
\hline $\begin{array}{l}\text { ER/PR status } \\
\text { ER+/PR+ } \\
\text { ER+/PR- } \\
\text { ER-/PR+ } \\
\text { ER-/PR- }\end{array}$ & $\begin{array}{l}10 \\
2 \\
0 \\
0\end{array}$ & $\begin{array}{l}76.92 \% \\
15.38 \% \\
0 \% \\
0 \%\end{array}$ \\
\hline $\begin{array}{l}\text { Vein Thrombosis } \\
\text { Subclavian Vein } \\
\text { Axillary Vein } \\
\text { Brachial Vein } \\
\text { Cephalic Vein } \\
\text { Side: } \\
\text { right } \\
\text { left }\end{array}$ & $\begin{array}{l}5 \\
5 \\
2 \\
1 \\
\\
7 \\
6\end{array}$ & $\begin{array}{l}38.46 \\
38.46 \\
15.38 \% \\
7.69 \% \\
53.85 \% \\
46.15 \%\end{array}$ \\
\hline
\end{tabular}

All patients of our casuistry had positive ER/PR receptor status and this accounts for a more favourable biological characteristic (low proliferative rates, diploidy, normal p53) and this allowed also to use hormonal treatment as it is the first choice medical treatment in the majoirity of elderly breast cancer $[7,8]$.

Four patients $(30.76 \%)$ of our casuistry had a moderate clinical stage (I-II) while 9 patients $(69.22)$ had a more severe clinical stage (III-IV).

Data from scientific literature shows that $48 \%$ of breast cancer cases occur in patients aged 65 and older, and more than $30 \%$ occur in those over the age of 70 $[8,9]$.

$\mathrm{BC}$, due to its indolence in elderly patients, is frequently diagnosed at a more advanced stage and in these cases local and systemic treatments are often less effective.

Although the most common presentations of breast cancer are a palpable mass, there are less common clinical features that must be considered, especially in the elderly, as thromboembolic events often involving the upper limbs.

VTE and cancer have a two-way clinical association: VTE may be the presenting symptom of an occult cancer or, on the other side, patients with clinically overt malignancy may develop VTE as a complication at any stage of their disease [5].

\section{Conclusions}

Atypical clinical presentations, such as thromboembolic events, especially involving the upper limbs, are often the first clinical symptoms of $\mathrm{BC}$ in elderly patients, and if promptly recognized, may allow an early diagnosis of malignancy in these kind of patients.

\section{List of abbreviations}

BC: Breast Cancer; ER+: estrogen receptor - positive status; ER-: estrogen receptor - negative status; PR+: progesterone receptor - positive status; PRprogesterone receptor - negative status; VTE: Venous Thromboembolism;

\section{Competing interests}

The authors declare that they have no competing interests.

\section{Authors' contributions}

RS: conception and design, interpetration of data, given final approval of the version to be published. RC: acquisition of data, drafting the manuscript, given final approval of the version to be published. RG: acquisition of data, drafting the manuscript, given final approval of the version to be published. PP: acquisition of data, drafting the manuscript, given final approval of the version to be published. GB: critical revision, interpretation of data, given final approval of the version to be published. VG: critical revision, interpretation of data, given final approval of the version to be published. AA: acquisition of data, drafting the manuscript, given final approval of the version to be published. MD: acquisition of data, drafting the manuscript, given final approval of the version to be published. GA: acquisition of data, drafting the manuscript, given final approval of the version to be published. BA: critical revision, interpretation of data, given final approval of the version to be published. SdF: conception and design, critical revision, given final approval of the version to be published. 


\section{Authors' information}

RS: Assistant Professor of Surgery at University Magna Graecia of Catanzaro, Head Master Training Programme in Wound Care, Vascular Surgeon at University Hospital of Catanzaro. RC: Post-Graduate Doctorate in Vascular Surgery at University "Federico II" of Naples. RG: Student School of Medicine at University Magna Graecia of Catanzaro. PP: Resident in Vascular Surgery Training Programme at University Magna Graecia of Catanzaro. GB: Research Fellow at University Magna Graecia of Catanzaro. VG: Associate Professor at University of Ferrara. AA: Aggregate Professor of Surgery at Naples University Federico II. MD: Aggregate Professor of Surgery at Naples University Federico II. GA: Aggregate Professor of Surgery at Naples University Federico II. BA: Associate Professor of Surgery at University "Federico II" of Naples. SdF: Full Professor of Surgery at University Magna Graecia of Catanzaro, Head of Vascular Surgery Training Programme at University Magna Graecia of Catanzaro, Head of PhD Programme in Phlebolymphology Clinical and Experimental, Chief Division of Vascular Surgery at University Hospital of Catanzaro.

\section{Declarations}

Publication of this article was funded by author's personal funds. This article has been published as part of BMC Surgery Volume 13 Supplement 2, 2013: Proceedings from the 26th National Congress of the Italian Society of Geriatric Surgery. The full contents of the supplement are available online at http://www.biomedcentral.com/bmcsurg/supplements/13/S2

\section{Authors' details}

${ }^{1}$ Interuniversity Center of Phlebolymphology - Headquorters at University Magna Graecia of Catanzaro - Viale Europa, Località Germaneto - 88100 Catanzaro, Italy. ${ }^{2}$ Department of Medical and Surgical Science-University Magna Gracia of Catanzaro - Viale Europa, Località Germaneto - 88100 Catanzaro, Italy. ${ }^{3}$ Department of Surgery - University of Ferrara, 44100 Ferrara, Italy. ${ }^{4}$ Department of General, Geriatric, Oncologic Surgery and Advanced Technologies, University "Federico II" of Naples. Via Pansini, 5 - 80131 Naples, Italy

Published: 8 October 2013

\section{References}

1. Pappo I, Karni T, Sandbank J, Dinur I, Sella A, Stahl-Kent V, Wasserman I, Halevy A: Breast cancer in the elderly: histological, hormonal and surgical characteristics. Breast 2007, 16(1):60-7.

2. Serra R, Buffone G, Montemurro R, de Franciscis S: Axillary vein thrombosis as the first clinical manifestation of inflammatory breast cancer: report of a case. Surg Today 2013, 43(1):100-2.

3. Serra R, Buffone G, Miglietta AM, Abonante S, Giordano V, Renne M, Lugarà M, de Franciscis S: Breast Cancer and Venous Disease: A Retrospective Cohort Study. Ann Vasc Surg 2013, 27(6):762-766.

4. Serra R, Buffone G, Perri P, Renne M, Amato B, de Franciscis S: Male breast cancer manifesting as Cephalic Vein Thrombosis in a 70-year-old patient. Ann Vasc Surg 2013, (doi 10.1016/j.avsg.2013.01.016.).

5. Kruger SJ: Breast Cancer presenting as subclavian/axillary deep vein thrombosis and upper limb lymphoedema. Ann R Coll Surg Eng 2012, 94:55-56.

6. Amato B, Rispoli C, lannone L, Testa S, Compagna R, Rocco N: Surgical margins of resection for breast cancer: Current evidence. Minerva Chirurgica 2012, 67(5):445-452.

7. Rispoli C, Rocco N, lannone L, Compagna R, Cacciapuoti MT, Bellino A, Amato $B$ : Breast reconstruction in older women: $\mathrm{A}$ growing request. $B M C$ Geriatrics 2009, 9(SUPPL. 1):A46.

8. Wildiers H, Paridaens R: Taxanes in elderly breast cancer patients. Cancer Treat Rev 2004, 30(4):333-42.

9. Rispoli C, Rocco N, lannone I, Amato B: Developing guidelines in geriatric surgery:role of the grade system. BMC Geriatrics 2009, 9(SUPPL 1), article n.A99.

doi:10.1186/1471-2482-13-S2-S39

Cite this article as: Serra et al.: Upper extremity vein thrombosis: an alert symptom of breast cancer in elderly patients. Experience on personal casuistry and review of the literature. BMC Surgery 2013 13(Suppl 2):S39.

\section{Submit your next manuscript to BioMed Central and take full advantage of:}

- Convenient online submission

- Thorough peer review

- No space constraints or color figure charges

- Immediate publication on acceptance

- Inclusion in PubMed, CAS, Scopus and Google Scholar

- Research which is freely available for redistribution

Submit your manuscript at www.biomedcentral.com/submit 